Journal Homepage: -www.journalijar.com
ISSN NO. 2320-5407

RESEARCH ARTICLE

\title{
LEVEL OF TEACHERS' CAPABILITY IN MEETING THE NEW GEC REQUIREMENTS OF CHED: INPUT TO PROPOSED TEACHERS CAPABILITY TRAINING.
}

Caezar D. Pamin, Ph. D.

Faculty, College of Teacher Education Laguna State Polytechnic University Santa Cruz, Laguna, Philippines.

\section{Manuscript Info}

Manuscript History

Received: 16 March 2019

Final Accepted: 18 April 2019

Published: May 2019

\section{Abstract}

This study entitled "Level of Teachers Capability to meet the new GEC requirements of CHED: input to proposed teachers capability training" aimed to find out the effect of Teachers Capability on the Implementation of New GEC Curriculum to the teachers of selected higher educational institutions in the province of Laguna provide an insight on how to implement the GEC curriculum. Thus, this study determined answer to the following: Specifically, it sought answers to the following questions: 1 . What is the level of teacher's competence of higher educational institutions towards the implementation of new general education curriculum in terms of CHED Seminar, Leadership, and Planning? 2. What is the level of implementation of new general education curriculum when it comes to Monitoring, Coaching, Review; and Evaluation? 3. Is there any significant impact of teacher's competence of higher educational institutions towards the implementation of new general curriculum?

The researcher made use of the descriptive method of research in order to elicit relevant information about Teachers Competence of Higher Education Institutions toward the Implementation of New General Curriculum. The statistical tools used were weighted mean, standard deviation, and one-way ANOVA.

The statistical treatment of data revealed the following findings. The level of teacher's competence in terms of CHEDseminar got the total weighted mean of 3.23 and was interpreted as "sometimes" while in terms of leadership got the total weighted mean of 4.48 and was interpreted as "always" while in terms of planning got the total weighted mean of 4.36and was interpreted as "always". The level of implementation of new general education curriculum in terms of monitoring got a mean value of 4.08 and was interpreted as "often" while in terms of coaching got the total weighted mean of 4.26 and was interpreted as "always" while in terms of review got the total weighted mean of 4.09 and was verbally interpreted as "Often" while in terms of evaluation got a mean value of 4.17 and verbally interpreted as "often". The impact of teacher's capability in terms of implementation of new GEC curriculum. It further shows that impact has F of 12.36 and F-

critical of 2.12 which is less than the level of significance $a=0.05$ verbally interpreted as "Significant". 
The findings to this study suggest that Teachers Competence bears a significant relationship with the Implementation of New GEC curriculum. The level of teacher's capability in terms of CHED Seminar, leadership and planning was marked as significant to the implementation of new GEC curriculum in terms of monitoring, coaching, review, and evaluation to which the study has suggested special encouragement by all personnel involved with the group. More investigations of this kind should be conducted to foster international exchange of ideas, research findings, and intercultural dialogue.

Copy Right, IJAR, 2019,. All rights reserved.

\section{Introduction: -}

One of the outlining challenges in the Philippine Education System in the past decades is the implementation of K12 Program which mandates the addition of two years in the traditional ten years pre-university policy. This curriculum promised to offer several benefits to the Filipino nation including ensuring, integrated and seamless learning and building proficiency through language to gear up for the future.

This major shift in the dynamics of basic education prompted changes in the curriculum of higher education. One critical implication of this is the integration of College General Education courses (i.e., mandatory courses for all undergraduate students irrespective of their majors) in grade 11 and grade 12 curriculum; the same other general education courses in literature, math, sciences and social science. This change bought out about the implementation of College Readiness Standards (CEB Resolution No. 289-2011) authored by the Commission on Higher Education (CHED) Technical Panel for General Education. The said resolution aims to allow higher learning institution to tighten the focus of their undergraduate curricula.

New General Education Curriculum (CMO No. 20, series of 2013) highlighted out as the Revised General Curriculum (GEC) for 2018, the core courses which includes Purposive Communication, Understanding the self, Readings in Philippine History, The Contemporary World, Mathematics in the Modern World, Art Appreciation, Science Technology and Society, Ethics and The Life and Works of Rizal.

The elective courses must: Conform to the philosophy and goals of general education, apply an inter or crossdisciplinary perspective and Draw materials cases or examples from Philippine realities and experience and not just from those of other countries.

Electives must cover at least two domains of knowledge (arts and humanities, social sciences and philosophy; and science, technology and mathematics)

Education as the backbone of development in any nation and it improves the quality of one's life its implementer must be a stronghold for them to achieve the goal that they're trying to attain; production of quality, potential learners. (Oyedji, 1998) Communication is what evaluation strategies among college institutions in Laguna.

Teacher do with students it is a skill that roots out the writing, speaking, and explaining context in different purposes ability. CHED aims for a higher learning for students to meet the $21^{\text {st }}$ century educational demands.

New GEC was implemented in the academic year of 2018-2019 if there is another curriculum there's also conflict or changes in the school's managerial capabilities. The researchers urge to assess this new course's developing performance. Benardin and Russel (1988) defined that performance as the record of the outcome produced on the specified function. Thus, (Wahjosumidjo, 1996: 126) explained that performance is an achievement or contribution which achieves the goal.

\section{Objectives:-}

This study determined the teacher capabilities of higher educational institutions towards the implementation of new general education curriculum. Specifically, the study sought answers to the following questions. 
1. What is the level of teacher's capability of higher educational institutions towards the implementation of new general education curriculum in terms of:

1. CHED 54hrs Seminar;

2. Leadership; and

3. Planning?

2. What is the level of implementation of new general education curriculum when it comes to:

1. Monitoring;

2. Coaching;

3. Review; and

4. Evaluation?

3. Is there any significant impact of teacher's capability of higher educational institutions towards the implementation of new general curriculum?

\section{Methodology:}

The descriptive method of research was used in this study. According to Key (1997), descriptive research is used to obtain information concerning the current status of the phenomena to describe "what exists" with the respect to variables or conditions in a situation. The descriptive method will be used to analyze the Level of Teachers Capability to meet the new GEC requirements of CHED

Key adds that the principal aims in employing this method were to describe the nature of the situation as it exists at the time of the study and to explore the causes and the effect of certain phenomena.

Purposive sampling will be used in the selection of the respondents. Purposive sampling is a common method of non-probability sampling. Non-probability sampling does not involve random selection of sample elements. (Parreno\& Jimenez, 2006).

\section{Literature review:}

Prospero "Popoy" de Vera, CHED officer-in-charge, said CHED Memorandum Order 20, series of 2013 otherwise known as "General Education Curriculum: Holistic Understandings, Intellectual and Civic Competencies" has been signed by the technical panel, and will be implemented starting academic year 2018-2019 with the aim of ensuring that there is no duplication of subjects between basic and higher education. The new general education curriculum has been aligned with the advanced subjects now to be taken in Senior High School (Grades 11 and 12).

According to Alcober Neil (2018)“The general education curriculum has been reduced from 63 units to 36 units because a lot of subjects are now on Senior High School," De Vera said, adding that the new curriculum focuses on the skills that are needed in the university level.

The new curriculum is aligned with the K-to-12 [Kindergarten to Grade 12] program, the Philippine Qualifications Framework (PQF) and the ASEAN Qualifications Framework (AQF). It is also outcomes-based as it prepares students to become job-ready when they graduate.Under the new curriculum, five-year courses like engineering and nursing will be reduced to four years while four-year arts and sciences programs will remain at four years.

Alcober (2018) cite that "Our new general education curriculum really was planned in senior high school that many of the things that used to be. The general education curriculum has been brought down in the senior high school, so the required courses in college now, general education curriculum is multi-disciplinary and it was not anymore 60 units or 30 units," the CHED chief explained.

The revised general education curriculum, part of the K-to-12 program, aims to expose college students to various domains of knowledge and ways of comprehending social and natural realities, developing in the process intellectual competencies and civic capacities.

Under the K-to-12 program, Filipino students will have to go through kindergarten, six years of elementary, four years of junior high school (Grade 7-10) and two years of senior high school (Grade 11-12). 
General education includes subjects such as English, Filipino and Natural Science, which will be transferred to the high school phase of basic education.

Various researcher had tried to interpret the managerial capability of school heads in different manner. Palattao (2013) assessed the management of the public secondary schools in terms of content/expertise of teachers, availability/adequacy of textbooks and other instructional materials, the use of strategies in teaching Grade 7 Mathematics, and the use of tools in assessing the students' learning. A survey questionnaire was used to gather the data for this study. The result of the assessment served as the basis in the formulation of recommendation/suggestion to help in the successful implementation of K-12 Program. The finding that the overall readiness of teachers in terms of content is fair, instructional materials are moderately adequate and the teachers are moderately ready in using require congruent to the skills as spelled out in the Grade 7 math curriculum.

On the other hand, Mushtaq's (2014) study was designed to find out the different type of management structures at secondary school level particularly in private sector. The data was collected by analyzing the prospectus, handouts, and pamphlets available to thee researcher. It was found that there are seven broad types of management structure in different schools. The structures were ranked by giving them management structure score on the basis of the variety, horizontal layout, vertical layout and gender wise positions held by different key figures running the schools from day to day. It was recommended that a training mechanism may be developed to provide training to private school administrators, the school should display their rules and regulations in black and white, a minimum qualification for managers and schools' administrators may also be made compulsory by the boards.

While, Ferrancullo et al. (2012) assessed the management functions in relation to performance of barangay committees in the Municipality of Romblon, Romblon. Based from the findings of this study, the following conclusions were drawn, most respondents agreed that barangay committee are effective on their management functions in terms of planning, organizing, directing and controlling; majority of the respondents perceived that the level of performance of barangay committees were "very satisfactory" in terms of peace and order, agriculture, beautification, education, health and finance, Committees' performance in terms peace and order, agriculture, education and health are not significantly related to management functions in terms of planning, organizing, directing and controlling thus, null hypothesis is accepted.

Falogne (2012) assessed and looked into the status of management functions of public secondary school principals in the Division of Romblon, specifically, in terms of 1) planning; 2) budgeting; 3) organizing and 4) evaluating. Using the descriptive-developmental method of research, the study employed the Input-Process and Output assessment model to determine the extent to which the secondary principals' management functions and the various student services have met the standards required of quality delivery services. Using the multi-stage purposive sampling techniques, a total of three hundred thirty-three (333) respondents were drawn from eleven participating schools composed of program supervisors, principals, teacher and students such as books, memoranda, circulars and teachers' magazine were utilized as data gathering materials. Data gathered were treated with the use of descriptive statistics which includes percentage, weighted mean, F-test and Pearson Product Moment Correlation Coefficient.

Findings of the study revealed that management functions of secondary school principals in the Division of Romblon have been generally perceived as very satisfactory with planning and reviewing as first and last respectively among those perceived by the respondents as very satisfactory. A no significant difference in the perception of the four groups of respondents was found out in the areas planning, budgeting, organizing and reviewing principals; however, a significant difference was revealed in the area of leading functions, moreover all variables in management functions have been found to be related with each other.

The above-mentioned studies are related to the present study. They investigated the managerial capabilities of school heads in many ways as well as how this variable is related to the school outcomes.

According to study made by Les Beli (2009) strategic planning, in the form of school improvement planning has become the dominant approach to school management in English Schools. This has evolved from earlier forms of strategic planning and has significant inherent weaknesses that undermine the extent to which school improvement planning can contribute to the effective management of schools. The development of school improvement planning is examined in this article and its weaknesses analyzed implied models of school management and leadership, the legacy of school effectiveness and improvement research and the role of the school principal are considered. Based 
on this analysis, an alternative approach to planning in schools and to organization and more flexible approach to school organization and leadership is proposed that is grounded in a shorter planning time scale and the development of structure that facilitate involvement, cooperation and collaboration.

Benito-Corre (2013) looked into the decision-making practices employed by the school principals in selected Basic Education Private Schools of CALABARZON. The study revealed that the most commonlyemployed DecisionMaking Practices of School Principals as perceived by the principals themselves and the teacher under their supervision. Findings revealed that school principals oftentimes observed the Vroom-Jago Model, a participative style in decision-making. The findings indicate that a statistically significant difference was also present between the principal and teacher groups regarding to their perceptions on the decision-making practices of the school principals.

Based on the findings, the personal contribution of the researcher to the decision-making practices of school principals is a guide in decision-making for school administrators through the different exercises in decision-making using the five scenarios in educational setting conceptualized by the researcher, as an offshoot of her study and based on the decision-making models authorized by Ray and The Team Handbook.

This study investigated whether curriculum modifications predicted student and teacher behaviors related to the general education curriculum and if there were differences in ecological, student, and teacher variables depending on the presence of such curriculum modifications. The study observed 45 high school students with disabilities during instruction in core content areas. Findings indicated that there were significant differences in student and teacher variables depending on the presence of curriculum modifications. When curriculum modifications were provided, students were engaged in more academic-related responses and fewer competing behaviors and teachers were engaged in fewer classroom management activities. Implications and recommendations from these findings are provided pertaining to the importance and implementation of curriculum modifications for students with disabilities in general education settings.

According to Kaufman and Herman presented a clear picture of the process of the strategic planning from start to finish. This process includes selecting desired results, assessing needs to formulate new purposes, developing and implementing action plans, and evaluating the success of the strategic plan. It was important for school to implement review in their schools in all areas to verify if the objectives were achieved.

Review draws the different strands of the program to bring together the costs of indifferent resource inputs as well as analyze of how such inputs can be transformed into outputs by allocating educational spending in productive ways. It will look at the spending choices and trade-off countries face in striving for this and will seek to synthesize research-based evidence on effective resource use in the school sector and disseminate this knowledge among countries, identify innovative and successful policy initiatives and practices, facilitate exchanges of lesson and experiences among countries, and identify policy options for policy makers to consider (OEDC, 2013).

According to Allinder (2014) that examined the effects of combining curriculum-based measurement in mathematics computation with teachers' self-monitoring of instructional changes on academic progress of elementary students with learning disabilities and mild mental disabilities. Participating teachers were assigned to a control group that did not use curriculum-based measurement. Teachers in the curriculum-based measurement with self-monitoring group also used this monitoring system; in addition, they used a self-monitoring procedure that was structured to guide them in analyzing student progress and the instructional plan they had been using with an individual student. Results indicated that teacher who self-monitored their use of curriculum-based measurement revised their students' instructional plans in ways that differed significantly from those teachers who did not self-monitor all parts of curriculum-based measurement. Additionally, the combination of curriculum-based measurement and selfmonitoring resulted in significantly greater growth for students.

\section{Discussion:-}

Table 1 is the Level of Teacher's Capability in Terms of CHED 54hrs Seminar. It states that the first statement "Teachers are attending seminars and trainings with regards on the new general education curriculum." has a mean of 3.04and SD of 1.51 verbally interpreted as "Moderately Agree". The second statement "Teachers are obliged to attend trainings and enhancement seminars" has a mean of 3.53 and SD of 1.51 verbally interpreted as "Agree". The third statement "Teachers are updated with the upcoming curriculum strands" has a mean of 3.26 and SD 1.50 verbally interpreted as "Moderately Agree". The fourth statement "Teachers are oriented and trained on the CHED 
54hrs seminar" has a mean of 2.77 and SD of 1.45 verbally interpreted as "Moderately Agree". The fifth statement "Teacher is developing way to effectively implement the curriculum" has a mean of 3.53 and SD of 1.46 verbally interpreted as "Agree".

Table 1:-Level of Teachers Capability of Higher Educational Institution intermsof CHED 54 hours seminar.

\begin{tabular}{|c|c|c|c|c|}
\hline CHED 54hrs. Seminar & Mean & SD & Remarks & $\begin{array}{c}\text { Verbal } \\
\text { Interpretation }\end{array}$ \\
\hline $\begin{array}{l}\text { 1. Teachers are attending seminars and } \\
\text { trainings with regards on the new general } \\
\text { education curriculum. }\end{array}$ & 3.04 & 1.51 & $\begin{array}{l}\text { Moderately } \\
\text { Agree }\end{array}$ & Sometimes \\
\hline $\begin{array}{l}\text { 2. Teachers are obliged to attend trainings and } \\
\text { enhancement seminars. }\end{array}$ & 3.53 & 1.51 & Agree & Often \\
\hline $\begin{array}{l}\text { 3. Teachers are updated with the upcoming } \\
\text { curriculum strands. }\end{array}$ & 3.26 & 1.50 & $\begin{array}{l}\text { Moderately } \\
\text { Agree }\end{array}$ & Sometimes \\
\hline $\begin{array}{l}\text { 4. Teachers are oriented and trained on the } \\
\text { CHED 54hrs seminar. }\end{array}$ & 2.77 & 1.45 & $\begin{array}{l}\text { Moderately } \\
\text { Agree }\end{array}$ & Sometimes \\
\hline $\begin{array}{l}\text { 5. Teacher is developing way to effectively } \\
\text { implement the curriculum. }\end{array}$ & 3.53 & 1.46 & Agree & Often \\
\hline Weighted Mean & \multicolumn{4}{|c|}{3.23} \\
\hline Verbal Interpretation & \multicolumn{4}{|c|}{ Sometimes } \\
\hline
\end{tabular}

Theweighted mean of 3.23 reveals that the Teacher's Capability in Terms of CHED 54hrs Seminar verbally interpreted as "Sometimes".

\begin{tabular}{|l|l|l|l|l|l|l|}
\hline Scale & & Range & & Remarks & & $\begin{array}{l}\text { Verbal } \\
\text { Interpretation }\end{array}$ \\
\hline 5 & & $5.00-4.21$ & $\begin{array}{l}\text { Strongly } \\
\text { Agree }\end{array}$ & & Always & \\
\hline 4 & & $4.20-3.41$ & Agree & & & Often \\
\hline 3 & $2.61-3.40$ & $\begin{array}{l}\text { Moderately } \\
\text { Agree }\end{array}$ & Sometimes & & \\
\hline 2 & & $1.81-2.60$ & Disagree & & Seldom & \\
\hline 1 & & $1.00-1.80$ & $\begin{array}{l}\text { Strongly } \\
\text { Disagree }\end{array}$ & Never & & \\
\hline
\end{tabular}

Table 2:-is the Level of Teacher's Capability in Terms of Leadership. It states that the first statement "Perform responsibilities in accordance to the goals of the subject" has a mean of 4.42 and SD of 0.69 verbally interpreted as "Strongly Agree". The second statement "Submit the required report promptly" has a mean of 4.32 and SD of 0.61 verbally interpreted as "Strongly Agree". The third statement "Show consistency in the implementation of policies and procedures" has a mean of 4.53 and SD 0.54 verbally interpreted as "Strongly Agree". The fourth statement "Maintain the professional behavior" has a mean of 4.55 and SD of 0.70 verbally interpreted as "Strongly Agree". The fifth statement "Spend sufficient time for instructional supervision" has a mean of 4.57 and SD of 0.75 verbally interpreted as "Strongly Agree".

The weighted mean of 4.48reveals that the Teacher's Capability in Terms of Leadership verbally interpreted as "Always".

According to Thomas (2012) research on leadership behaviors on collaborative environments, leadership skills will be enhanced by good knowledge and experience of his field. His leadership potential will also depend on aspects of his emotional awareness level of fluid intelligence. Thomas referred to the need for the principal to organize communication channels to facilitate information flow. The effective principal reflects openness to ideas and a willingness to listen to others. This reflective listening skill promotes a higher level of trust when it comes to shared decision making.

In Addition, leadership involves influence that a manager uses to inspire action taken by others. Effective leader will have enthusiastic subordinates about exerting efforts to attain the organizational objectives. 
Table 2:-Level of Teachers Capability of Higher Educational Institution In Terms of Leadership

\begin{tabular}{|c|c|c|c|c|}
\hline Leadership & Mean & SD & Remarks & $\begin{array}{c}\text { Verbal } \\
\text { Interpretation }\end{array}$ \\
\hline $\begin{array}{l}\text { 1. Perform responsibilities in accordance to } \\
\text { the goals of the subject. }\end{array}$ & 4.42 & 0.69 & Strongly Agree & Always \\
\hline 2. Submit the required report promptly. & 4.32 & 0.61 & Strongly Agree & Always \\
\hline $\begin{array}{l}\text { 3. Show consistency in the implementation } \\
\text { of policies and procedures. }\end{array}$ & 4.53 & 0.54 & Strongly Agree & Always \\
\hline 4. Maintain the professional behavior. & 4.55 & 0.70 & Strongly Agree & Always \\
\hline $\begin{array}{l}\text { 5. Spend sufficient time for instructional } \\
\text { supervision. }\end{array}$ & 4.57 & 0.75 & Strongly Agree & Always \\
\hline Weighted Mean & \multicolumn{4}{|c|}{4.48} \\
\hline Verbal Interpretation & \multicolumn{4}{|c|}{ Always } \\
\hline
\end{tabular}

\begin{tabular}{|c|c|c|c|}
\hline $\begin{array}{c}\text { Legend: } \\
\text { Scale }\end{array}$ & Range & Remarks & Verbal Interpretation \\
\hline 5 & $4.21-5.00$ & Strongly Agee & Always \\
\hline 4 & $3.41-4.20$ & Agree & Often \\
\hline 3 & $2.61-3.40$ & Moderately Agree & Seldom \\
\hline 2 & $1.81-2.60$ & Disagree & Never \\
\hline 1 & $1.00-1.80$ & Strongly Disagree & \\
\hline
\end{tabular}

Table 3 is the Level of Teacher's Capability in Terms of Planning. It states that the first statement "Sets target within the needs of the school" has a mean of 4.57 and SD of 0.67 verbally interpreted as "Strongly Agree". The second statement "Align target with the school goals" has a mean of 4.15 and SD of 0.66 verbally interpreted as "Agree". The third statement "Consider priorities in planning activities of the school" has a mean of 4.47 and SD 0.77 verbally interpreted as "Strongly Agree". The fourth statement "Develop alternative plans for problem that will arise in the future" has a mean of 4.23 and SD of 0.78 verbally interpreted as "Strongly Agree". The fifth statement "Assess the plans after the implementation" has a mean of 4.38 and SD of 0.84 verbally interpreted as "Strongly Agree".

The weighted mean of 4.36 reveals that the Teacher's Capability in Terms of Planning verbally interpreted as "Always".

Planning is the part of management concerned with creating procedures, rules and guidelines for achieving a stated objective. Planning is carried out at both the macro and micro level. Managers need to create broad objectives and mission statements as well as look after the day to day (Kasia, 2013).

Furthermore, planning is very important, it sets the objectives and determine course of action for achieving those objectives. As managers, they should be aware of the conditions facing the school and forecast future conditions. It also requires them to be good decision makers. The data only showed that the school heads' managerial capability was given importance to succeed with the execution of GEC Curriculum program.

Table 3:-Level of Teachers Capability of Higher Educational Institution in terms of Planning

\begin{tabular}{|l|c|c|c|c|}
\multicolumn{1}{|c|}{ Planning } & Mean & SD & Remarks & $\begin{array}{c}\text { Verbal } \\
\text { Interpretation }\end{array}$ \\
\hline 1. Sets target within the needs of the school. & 4.57 & 0.67 & Strongly Agree & Always \\
\hline 2. Align target with the school goals. & 4.15 & 0.66 & Agree & Often \\
\hline $\begin{array}{l}\text { 3. Consider priorities in planning activities } \\
\text { of the school. }\end{array}$ & 4.47 & 0.77 & Strongly Agree & Always \\
\hline $\begin{array}{l}\text { 4. Develop alternative plans for problem } \\
\text { that will arise in the future. }\end{array}$ & 4.23 & 0.78 & Strongly Agree & Always \\
\hline $\begin{array}{l}\text { 5. Assess the plans after the } \\
\text { implementation. }\end{array}$ & 4.38 & 0.84 & Strongly Agree & Always \\
\hline
\end{tabular}




\begin{tabular}{|l|c|}
\hline Weighted Mean & $\mathbf{4 . 3 6}$ \\
\hline Verbal Interpretation & Always \\
\hline
\end{tabular}

\begin{tabular}{|c|c|c|c|}
\hline $\begin{array}{c}\text { Legend: } \\
\text { Scale }\end{array}$ & Range & Remarks & Verbal Interpretation \\
\hline 5 & $4.21-5.00$ & Strongly Agee & Always \\
\hline 4 & $3.41-4.20$ & Agree & Often \\
\hline 3 & $2.61-3.40$ & Moderately Agree & Seldom \\
\hline 2 & $1.81-2.60$ & Disagree & Never \\
\hline 1 & $1.00-1.80$ & Strongly Disagree & \\
\hline
\end{tabular}

Furthermore, planning is very important, it sets the objectives and determine course of action for achieving those objectives. As managers, they should be aware of the conditions facing the school and forecast future conditions. It also requires them to be good decision makers. The data only showed that the school heads' managerial capability was given importance to succeed with the execution of GEC Curriculum program.

\section{Level of Implementation of New General Education Curriculum: -}

Table 4 is the Level of Implementation of New General Education Curriculum in Terms of Monitoring. It states that the first statement "Monitor if the school follows the new General Education Curriculum." has a mean of 4.19 and SD of 1.08 verbally interpreted as "Agree". The second statement "Monitor the adequacy of funding requirements for the full implementation of GEC" has a mean of 4.17 and SD of 1.03 verbally interpreted as "Agree". The third statement "The administration monitors the teaching staff if they're attending trainings" has a mean of 3.92 and SD 1.12 verbally interpreted as "Agree". The fourth statement "The school make sure if their facilities are enables to suffice the needs for new courses" has a mean of 4.09 and SD of 1.06 verbally interpreted as "Agree". The fifth statement "The school administrators are monitoring their students' evaluation states if their implementation is properly scattered" has a mean of 4.02 and SD of 1.07 verbally interpreted as "Strongly Agree".

The weighted mean of 4.08 reveals that the Implementation of New General Education Curriculum in Terms of Monitoring verbally interpreted as "Often".

As monitoring is the phase where the school heads monitor the work activities of teachers and nonteaching staff and progress of work output. He is expected to address factors that either help or hinder effective work performance and design tracking tools or monitoring strategies as may be needed. Essentially, the focus is on the critical function and strategies shift of school heads as front runners of development planning, with emphasis on the strategic role of being an enabler/coach/mentor rather than a mere evaluator. At this stage, school heads should fully exercise or practice this management development intervention in enhancing the potentials of every staff under them. The school heads should periodically check on progress and quality of work output of the faculty and other school personnel (OECD, 2009).

Table 4:-Level of Implementation of New General Education Curriculum in terms of Monitoring.

\begin{tabular}{|l|c|c|c|c|}
\hline \multicolumn{1}{|c|}{ Monitoring } & Mean & SD & Remarks & $\begin{array}{c}\text { Verbal } \\
\text { Interpretation }\end{array}$ \\
\hline $\begin{array}{l}\text { 1. Monitor if the school follows the new } \\
\text { General Education Curriculum. }\end{array}$ & 4.19 & 1.08 & Agree & Often \\
\hline $\begin{array}{l}\text { 2. Monitor the adequacy of funding } \\
\text { requirements for the full implementation of } \\
\text { GEC. }\end{array}$ & 4.17 & 1.03 & Agree & Often \\
\hline $\begin{array}{l}\text { 3. The administration monitors the teaching } \\
\text { staff if they're attending trainings. }\end{array}$ & 3.92 & 1.12 & Agree & Often \\
\hline $\begin{array}{l}\text { 4. The school make sure if their facilities are } \\
\text { enables to suffice the needs for new courses. }\end{array}$ & 4.09 & 1.06 & Agree & Often \\
\hline $\begin{array}{l}\text { 5. The school administrators are monitoring } \\
\text { their students evaluation states if their } \\
\text { implementation is properly scattered. }\end{array}$ & 4.02 & 1.07 & Agree & Often \\
\hline Weighted Mean & & & $\mathbf{4 . 0 8}$ \\
\hline
\end{tabular}




\section{Verbal Interpretation}

\section{Often}

\begin{tabular}{|c|c|c|c|}
\hline $\begin{array}{c}\text { Legend: } \\
\text { Scale }\end{array}$ & Range & Remarks & Verbal Interpretation \\
\hline 5 & $4.21-5.00$ & Strongly Agee & Always \\
\hline 4 & $3.41-4.20$ & Agree & Often \\
\hline 3 & $2.61-3.40$ & Moderately Agree & Sometimes \\
\hline 2 & $1.81-2.60$ & Disagree & Seldom \\
\hline 1 & $1.00-1.80$ & Strongly Disagree & Never \\
\hline
\end{tabular}

Moreover, excellent monitoring in the implementation of GEC Curriculum program is an integral part of every project from start to finish. This will ensure that the program is implemented as per schedule as well as it should appear on the curriculum plan that involve all stakeholders.

Table 5 is the Level of Implementation of New General Education Curriculum in Terms of Coaching. It states that the first statement "Teachers prepare forms, records and report as directed" has a mean of 4.53 and SD of 0.58 verbally interpreted as "Strongly Agree". The second statement "Teachers are knowledgeable about curriculum component and understand the instructional design of how the curriculum meets the standards" has a mean of 4.36 and SD of 0.65 verbally interpreted as "Strongly Agree". The third statement "Teachers build an interactive classroom environment focused on the content and learning strategies embedded in the curriculum" has a mean of 4.30 and SD 0.57 verbally interpreted as "Strongly Agree". The fourth statement "Teachers have been trained to an advanced level of delivery and using the instructional materials as designed" has a mean of 4.04 and SD of 1.04 verbally interpreted as "Agree". The fifth statement "Teachers meet regularly with the dean to review the skills assessment data and to assess the outcomes goals" has a mean of 4.08 and SD of 1.19 verbally interpreted as "Strongly Agree".

The weighted mean of 4.26 reveals that the Implementation of New General Education Curriculum in Terms of Coaching verbally interpreted as

"Always".

Table 5: -Level of Implementation of New General Education Curriculum in Terms of Coaching.

\begin{tabular}{|l|c|c|c|c|}
\hline \multicolumn{1}{|c|}{ Coaching } & Mean & SD & Remarks & $\begin{array}{c}\text { Verbal } \\
\text { Interpretation }\end{array}$ \\
\hline $\begin{array}{l}\text { 1. Teachers prepare forms, records and report as } \\
\text { directed. }\end{array}$ & 4.53 & 0.58 & Strongly Agree & Always \\
\hline $\begin{array}{l}\text { 2.Teachers are knowledgeable about curriculum } \\
\text { component and understand the instructional } \\
\text { design of how the curriculum meets the standards. }\end{array}$ & 4.36 & 0.65 & Strongly Agree & Always \\
\hline $\begin{array}{l}\text { 3. Teachers build an interactive classroom } \\
\text { environment focused on the content and learning } \\
\text { strategies embedded in the curriculum. }\end{array}$ & 4.30 & 0.57 & Strongly Agree & Often \\
\hline $\begin{array}{l}\text { 4. Teachers have been trained to an advanced } \\
\text { level of delivery and using the instructional } \\
\text { materials as designed. }\end{array}$ & 4.04 & 1.04 & Agree & Often \\
\hline $\begin{array}{l}\text { 5. Teachers meet regularly with the dean to } \\
\text { review the skills assessment data and to assess the } \\
\text { outcomes goals. }\end{array}$ & 4.08 & 1.19 & Agree & $\mathbf{4 . 2 6}$ \\
\hline Weighted Mean & & \multicolumn{2}{c|}{ Always } \\
\hline Verbal Interpretation & & & \\
\hline
\end{tabular}




\begin{tabular}{|c|c|c|c|}
\hline $\begin{array}{c}\text { Legend: } \\
\text { Scale }\end{array}$ & Range & Remarks & Verbal Interpretation \\
\hline 5 & $4.21-5.00$ & Strongly Agee & Always \\
\hline 4 & $3.41-4.20$ & Agree & Often \\
\hline 3 & $2.61-3.40$ & Moderately Agree & Seldom \\
\hline 2 & $1.81-2.60$ & Disagree & Never \\
\hline 1 & $1.00-1.80$ & Strongly Disagree & \\
\hline
\end{tabular}

According to Lofthouse, et. al. (2010) teacher coaching in school takes various forms, but is commonly conceived as a means of providing personalized professional support to teachers through discussion about their practice. Coaching takes time to organize and facilitate within any organization, and as time is precious in all schools it is important that coaching, where used, work to maximum effect.

It means that there is a significant relationship of school's educational resources to the level of implementation of GEC Curriculum program along with coaching.

Table 6 is the Level of Implementation of New General Education Curriculum in Terms of Review. It states that the first statement "Review the progress of implementing GEC mission and goals" has a mean of 4.08 and SD of 1.09 verbally interpreted as "Agree". The second statement "Identify if there have been external factors that impact the curriculum (e.g. community, parents)" has a mean of 3.87 and SD of 1.19 verbally interpreted as "Agree". The third statement "Review priorities, comment on curriculum implementation and provide course correction" has a mean of 3.89 and SD 1.15 verbally interpreted as "Agree". The fourth statement "Document students" academic achievement and assessment of student learning outcomes" has a mean of 4.36 and SD of 0.74 verbally interpreted as "Strongly Agree". The fifth statement "Identify the substantial circular changes in existing curriculum" has a mean of 4.28 and SD of 1.01 verbally interpreted as "Strongly Agree".

The weighted mean of 4.09 reveals that the Implementation of New General Education Curriculum in Terms of Reviewverbally interpreted as "Often".

Table 6:-Level of Implementation of New General Education Curriculum in

\begin{tabular}{|l|c|c|c|c|}
\hline \multicolumn{1}{|c|}{ Review } & Mean & SD & Remarks & $\begin{array}{c}\text { Verbal } \\
\text { Interpretation }\end{array}$ \\
\hline $\begin{array}{l}\text { 1. Review the progress of implementing GEC } \\
\text { mission and goals. }\end{array}$ & 4.08 & 1.09 & Agree & Often \\
\hline $\begin{array}{l}\text { 2. Identify if there have been external factors } \\
\text { that impact the curriculum (e.g. community, } \\
\text { parents) }\end{array}$ & 3.87 & 1.19 & Agree & Often \\
\hline $\begin{array}{l}\text { 3. Review priorities, comment on curriculum } \\
\text { implementation and provide course } \\
\text { correction. }\end{array}$ & 3.89 & 1.15 & Agree & Often \\
\hline $\begin{array}{l}\text { 4. Document students' academic achievement } \\
\text { and assessment of student learning outcomes. }\end{array}$ & 4.36 & 0.74 & Strongly & Agree \\
\hline $\begin{array}{l}\text { 5. Identify the substantial circular changes in } \\
\text { existing curriculum. }\end{array}$ & 4.28 & 1.01 & Strongly & Agree \\
\hline Weighted Mean & & & 4.09 & Always \\
\hline Verbal Interpretation & & & Often \\
\hline
\end{tabular}

\begin{tabular}{|c|c|c|c|}
\hline $\begin{array}{c}\text { Legend: } \\
\text { Scale }\end{array}$ & Range & Remarks & Verbal Interpretation \\
\hline 5 & $4.21-5.00$ & Strongly Agee & Always \\
\hline 4 & $3.41-4.20$ & Agree & Often \\
\hline 3 & $2.61-3.40$ & Moderately Agree & Seldom \\
\hline 2 & $1.81-2.60$ & Disagree & Never \\
\hline 1 & $1.00-1.80$ & Strongly Disagree & \\
\hline
\end{tabular}


According to Kaufman and Herman presented a clear picture of the process of the strategic planning from start to finish. This process includes selecting desired results, assessing needs to formulate new purposes, developing and implementing action plans, and evaluating the success of the strategic plan. It was important for school to implement review in their schools in all areas to verify if the objectives were achieved.

The data suggest a very high level of implementation in terms of review. The effective review of both program impact and evaluation can provide data with a more holistic perspective of the program and increased ability to identify and disseminate best GEC Curriculum program practices.

Table 7 is the Level of Implementation of New General Education Curriculum in Terms of Evaluation. It states that the first statement "Assess if the GEC is implemented as intended" has a mean of 4.32 and SD of 0.67 verbally interpreted as "Strongly Agree". The second statement "Assess if the program is achieving its intended outcomes." has a mean of 4.19 and SD of 1.04 verbally interpreted as "Agree". The third statement "Assess if the availability of equipment such as LCD projectors and learning materials for students." has a mean of 4.09 and SD 1.24 verbally interpreted as "Agree". The fourth statement "Evaluate if the program is technically efficient" has a mean of 4.19 and SD of 1.16 verbally interpreted as "Agree". The fifth statement "Assess if the GEC is adequate to achieve the overall objective of the Department of Education." has a mean of 4.08 and SD of 1.07 verbally interpreted as "Agree".

The weighted mean of 4.17 reveals that the Teacher's Capability in Terms of Review verbally interpreted as "Often".

Table 7:-Level of Implementation of New General Education Curriculum in

Terms of Evaluation

\begin{tabular}{|c|c|c|c|c|}
\hline Evaluation & Mean & SD & Remarks & $\begin{array}{c}\text { Verbal } \\
\text { Interpretation } \\
\end{array}$ \\
\hline $\begin{array}{l}\text { 1. Assess if the GEC is implemented as } \\
\text { intended. }\end{array}$ & 4.32 & 0.67 & $\begin{array}{l}\text { Strongly } \\
\text { Agree }\end{array}$ & Always \\
\hline $\begin{array}{l}\text { 2. Assess if the program is achieving its } \\
\text { intended outcomes. }\end{array}$ & 4.19 & 1.04 & Agree & Often \\
\hline $\begin{array}{l}\text { 3. Assess if the availability of equipment such } \\
\text { as LCD projectors and learning materials for } \\
\text { students. }\end{array}$ & 4.09 & 1.24 & Agree & Often \\
\hline $\begin{array}{l}\text { 4. Evaluate if the program is technically } \\
\text { efficient. }\end{array}$ & 4.19 & 1.16 & Agree & Often \\
\hline $\begin{array}{l}\text { 5. Assess if the GEC is adequate to achieve } \\
\text { the overall objective of the Department of } \\
\text { Education. }\end{array}$ & 4.08 & 1.07 & Agree & Often \\
\hline Weighted Mean & \multicolumn{4}{|c|}{4.17} \\
\hline Verbal Interpretation & & & Often & \\
\hline
\end{tabular}

\begin{tabular}{|c|c|c|c|}
\hline $\begin{array}{c}\text { Legend: } \\
\text { Scale }\end{array}$ & Range & Remarks & Verbal Interpretation \\
\hline 5 & $4.21-5.00$ & Strongly Agee & Always \\
\hline 4 & $3.41-4.20$ & Agree & Often \\
\hline 3 & $2.61-3.40$ & Moderately Agree & Sometimes \\
\hline 2 & $1.81-2.60$ & Disagree & Seldom \\
\hline 1 & $1.00-1.80$ & Strongly Disagree & Never \\
\hline
\end{tabular}

According to Eisner (2007), evaluation is used in education to perform a wide variety of functions. Of the functions of evaluation in education, the following five seem especially important to diagnose, to revise curricula, to compare, to anticipate educational needs and to determine if objectives have been achieved. It is, therefore, important to realize the existence of the various evaluation functions and the value of these functions to the education system. 
It means very high level of implementation in terms of evaluation means clearly understanding on what the program is supposed to accomplish and how it should be implemented. It is simply checking to make sure that GEC Curriculum program is running the way it was to be.

\section{Impact of Teachers Capability: -}

Table 8 interprets the impact of Teachers Capability in Terms of Implementation of New GEC Curriculum. It further shows that impact has a F of 12.36 and F-critical of 2.12 which is less than the level of significance $a=0.05$ verbally interpreted as "Significant".

Table 8:-Impact of Teachers Capability in Terms of Implementation of New

GEC Curriculum

\begin{tabular}{|c|c|c|c|}
\hline & F & F-critical & Verbal Interpretation \\
\hline Impact.... & 12.36 & 2.12 & Significant \\
\hline
\end{tabular}

Therefore, to meet the eligibility standards of the school, the teachers should follow the implemented policies and program regularly and well planned.

\section{Recommendations:}

1. In the light of the foregoing findings and conclusions of this study, the following recommendations are offered:

2. Teachers can use this study to expose students to the New Education Courses and make them aware to educational curriculum changes. This can also open up how teacher's teaching strategies matter most.

3. The School Administrators may use this as reference on how important effective educational plan is in teaching new education courses.

4. It is suggested that continuous application of best practices in terms of planning, leadership, decision-making and governance structure of school heads should be carried out.

5. It is advised that continuous monitoring should be done to the extent of use of the resources to support the program to achieve its greatest possible extent. The Dean of Arts and Sciences might be confronted with competing demands from variety of factors inside and outside the institution. Thus, distribution and allocation of these resources will be set to priorities for effectively and efficiency that will definitely affects the execution of GEC.

6. Consistency in applying top practices in terms of monitoring, coaching, review and evaluation of the Dean might be done to mobilize subordinates who want to struggle toward a common goal of full implementation of GEC; guidelines for monitoring, coaching, review and evaluation could be made for enhancing the program in the future.

7. Further study is recommended that would provide analysis and policy on how to distribute, utilize and manage educational resources to contribute in achieving the implementation of GEC.

8. An optional distribution, assessment and use of educational resources might be done to achieve both efficiency and equity objectives together, by ensuring that resources are channeled to where they are most needed. At the same time, process evaluation might be done to describe and assess the quality of implementation of GEC.

\section{References:-}

1. Allinder, R. M., (2014).. Effects of teacher self-monitoring on implementation of curriculum - based measurement and mathematics computationachievement of students with disabilities. Journal of the Hammil Institute on Disabilities.

2. OECD (2013). OECD Review of Policies to Improve the Effectiveness of Resource Use in Schools (School Resource Review): Design and Implementation Plan for the Review, OECD PublishingBenito - Corre, Juanita (2013). Decision- making practices of the schoolprincipals in selected basic education private schools in CALABARZON basis for a guide in decision - making for school administrators.Falogne, Jose (2012). Assessment of public secondary school principals' management functions and student services in a division: basis for the development of a handbook. Doctor of philosophy in education university: Phillippine Normal University, Philippines.

3. Ferran Cullo, Jean B. Mabunga, Shahanie F, Magada, Imee M. Magada (2012). Management fuctions in relation to performance of barangay committees in the municipality of Romblon, Romblo. Romblon State University, Odiongan Romblon

4. Mushtaq, Muhammad. (2014). Analysis of management structures of private sectorschool in Punjab. Master's thesis, University, Abraka, Nigeria, 
5. Palattao, Edgardo Bitanga (2013). Public secondary schools: an inquiry on the instructional readiness and management of grade 7 mathematics curriculum. Arellano Uniiversity.

6. Alcober Neil (2008). CHED to Implement new curriculum Retrieved from.https://www.manilatimes.net/chedto-implement-new-curriculum

7. Les Beli (2009). Strategic planning and school management: full of sound and fury, signifying nothing? Inaugural lecture given Tuesday, 19th february 2009. 